\title{
In Situ Monitoring of Mutagenicity of Air Pollutants in São Paulo City Using Tradescantia-SHM Bioassay
}

\author{
Maria Izildinha Ferreira ${ }^{1 *}$, Geraldo Stachetti Rodrigues ${ }^{2}$, Marisa Domingos ${ }^{3}$ and Paulo \\ Hilário do N. Saldiva ${ }^{4}$ \\ ${ }^{I}$ Administração Regional de Saúde; Secretaria Municipal da Saúde de São Paulo; Pça Centenário de Vila Prudente, \\ 108; CEP 03132-050; São Paulo - SP - Brazil. ${ }^{2}$ Embrapa Meio Ambiente; C. P. 069; CEP 13820-000; Jaguariúna - \\ SP-Brazil. ${ }^{3}$ Instituto de Botânica de São Paulo; C. P. 4005; CEP 0161-970; São Paulo - SP - Brazil. ${ }^{4}$ Laboratório de \\ Poluição Atmosférica Experimental; Departamento de Patologia; Faculdade de Medicina da Universidade de São \\ Paulo; Av. Dr. Arnaldo, 455; CEP 01246-903; São Paulo - SP - Brazil
}

\begin{abstract}
The Tradescantia stamen hair mutation assay (Trad-SHM) was employed for assessing the environmental mutagenesis in two areas of São Paulo City. The study sites were defined as follows: 1) Celso Garcia Avenue, an industrial area on the outskirts of the urban center (Belém neighborhood), with an average daily traffic volume of 8,750 vehicles; 2) Doutor Arnaldo Avenue, in downtown area (Pinheiros neighborhood), with a mostly residential and business offices occupation, with an average daily traffic volume of 46,125 vehicles. The negative control (background) site is located in the city of Jaguariúna, $138 \mathrm{~km}$ from São Paulo, in an area of low atmospheric pollution. The mutation frequency observed for Belém was similar to the background for clone 4430, whereas plants exposed in Pinheiros showed significant increases in mutation rate. Positive correlation was observed between mutation frequency and the levels of particulate matter in the atmosphere. This indicated a relationship between mutation frequency and the amount of atmospheric pollution present at the exposure sites in São Paulo City, with special reference to vehicular emissions.
\end{abstract}

Key words: Pollution, mutagenesis, bioassay, Tradescantia

\section{INTRODUCTION}

Literature has documented the fact that atmospheric pollution resulting from point sources such as industries and waste incinerators (Ferreira et al., 2000), or from mobile sources such as motor vehicles (Batalha et al., 1999), or in indoor environments (Miyazato, 2000), may contribute to increase the rate of genetic mutation in exposed organisms. It is plausible that such genetic alterations lead to deleterious consequences both to individual organisms, due to tumors and malignancies, and to whole populations, due to incidence of congenital diseases (Rodrigues, 1999c). This relationship between the genotoxic and carcinogenic properties of certain substances with their capability of inducing alterations in the human genome (Sadowska et al., 1994) shows the need for both monitoring the prevalence of the pollutants and developing protection measures against exposure to potentially genotoxic agents in the environment. Genetic toxicity bioassays are

\footnotetext{
* Author for correspondence
} 
especially useful for these tasks, especially when they are amenable to in situ studies, which allow evidencing directly the need for pollution control and preventive measures.

Among many bioassays useful for assessing environmental mutagenesis in situ, those that rely on higher plants as bioindicators show a number of advantages. They are usually low cost test systems not dependent on special structural or logistic facilities, and do not require excessive sample manipulation or complex sample concentration procedures (Rodrigues, 1999a). One good example of such bioassay especially valuable for atmospheric pollution studies is the Tradescantia stamen hair mutation assay (TradSHM) (Rodrigues, 1999b; Rodrigues et al., 1997). The exposure of Tradescantia to areas with high levels of atmospheric pollution cause increase in the frequency of somatic mutations in the stamen hairs (Schairer, 1979; Schairer and Sautkulis, 1982; Schairer et al., 1982; Sparrow and Schairer, 1974). Likewise, assessments of the mutagenicity of atmospheric pollutants such as $\mathrm{SO}_{2}, \mathrm{NO}_{2}, \mathrm{~N}_{2} \mathrm{O}$ and $\mathrm{O}_{3}$ with the Trad-SHM assay indicated that these pollutants induced high rate of mutations (Ichikawa, 1992). Heavy metals have also been assayed, and lead, zinc, copper, and cadmium, even when present at very low concentrations, caused increases in mutation rates (Lower et al., 1983a; Lower et al., 1978; Lower et al., 1983b). These studies showed the usefulness of the TradSHM assay for the detection of mutagenesis in polluted environments such as large metropolitan areas.

With a population of over 17 million people, a large industrial complex, and around 5.5 million motor vehicles, the Metropolitan Region of São Paulo spreads over $8,000 \mathrm{~km}^{2}$, is one of the large urban centers of the world. The main sources of atmospheric pollution in this city are motor vehicles, followed by industrial emissions and solid waste combustion.

The main objective of this study was to assess the possible association between the levels of atmospheric pollution, especially that ensuing from the traffic of motor vehicles in different areas of the city, and the mutation rate detected by the Tradescantia-SHM assay in these selected areas.

\section{MATERIAL AND METHODS}

São Paulo is geographically located in a lower compartment of the Paulista Atlantic Plateau. The urban area is surrounded by topographic units of the Serra do Mar reaching 1,100 m of altitude. This topographic complexity, associated with the proximity to the ocean and the intense urbanization, strongly influence the patterns of atmospheric circulation, causing conditions unfavorable to the dispersion of pollutants.

Two characteristic periods can be defined with regard to the atmospheric pollution problem and the frequency of high pollution concentration events in this city: one from October to April, rainy and more favorable to pollutant dispersion; and one from May to September, considered to be unfavorable for pollutant dispersion (CETESB, 1998). This study was carried out in the former period, in order to assess the prevalence of environmental mutagenicity in the period most favorable to pollution dispersion, or a minimum risk situation.

Two areas presenting contrasting motor vehicle traffic were studied, one (East) located in the Belém neighborhood (Celso Garcia Avenue), and another (South) in the Pinheiros neighborhood (Dr. Arnaldo Avenue). The control site of the study is located in the experimental farm of the Embrapa Environment Research Center, in the municipality of Jaguariuna, at $138 \mathrm{~km}$ from São Paulo, altitude $584 \mathrm{~m}$, total area of $96 \mathrm{~km}^{2}$ and a total population of 26,574 (IBGE, 1997), an area without major sources of atmospheric pollution.

\section{In Situ Experiment}

The assessment of in situ mutagenesis involved exposure of Tradescantia in $12 \times 17 \mathrm{~cm}$ pots containing a 3:1 mixture of sieved soil and vermiculite. The plants were watered three times a week and received $100 \mathrm{ml}$ of Hoagland nutrient solution every alternate week. Thirty pots containing 6 to 8 mature plants were taken to each exposure site in September 1998, and sampling began in December. Eleven samplings were carried out in Pinheiros, and nine in Belém. For each sampling, ten appropriate young inflorescences were used, and the stamens of the recently opened flowers were cut and placed on a microslide, and the number of hairs and mutation events counted under $30 \mathrm{x}$ magnification. A 
mutational event consists of one or a sequence of adjacent pink cells between the dominant blue cells, in any position of the stamen hair (Rodrigues, 1999a; Underbrink et al., 1973).

The data thus obtained for the two areas in São Paulo (as well as the data for the control site) were transformed in order to normalize the variance $(\mathrm{Y}=\operatorname{sqrt}[\mathrm{X}]+\operatorname{sqrt}[\mathrm{X}+1])$. The mutation frequencies obtained were analyzed for all sampling dates by ANOVA $(\alpha=0.05)$, and the contrasts within dates were compared by Student $t$ test $(\alpha=0.05)$ (Rodrigues, 1999a; Snedecor and Cochran, 1967). Data on the levels of atmospheric pollution obtained for the exposure period for São Paulo urban center (namely for $\mathrm{CO}, \mathrm{SO}_{2}, \mathrm{NO}_{2}$, and particulate matter) were correlated with mutation frequency data by linear regression analysis.

\section{RESULTS}

Very high mutation frequencies were obtained in Tradescantia exposed in the Pinheiros neighborhood, whereas in the Belém neighborhood the frequencies were equivalent to those observed in the unpolluted control site.

Although a general tendency for increased mutation rates for the Pinheiros neighborhood can be easily seen in Fig. 1, only two experimental periods effectively showed statistically significant differences in relation to the Belém neighborhood, namely one period in February and one in March (indicated by the letters "a" and "b" in Fig. 1). On the other hand, even though there is a tendency for higher mutation rates in Tradescantia exposed in São Paulo than in the Jaguariuna control site, these differences were not statistically significant. Once the association between exposure to areas with heavier vehicular traffic and increased mutation rates was confirmed with the Trad-SHM assay, a question remained regarding the specific genotoxic pollutants involved. To address this question, linear correlation analysis were carried out for mutation frequency and monthly and daily concentrations of $\mathrm{CO}, \mathrm{SO} 2, \mathrm{NO} 2$, and particulate matter (PM) for the experimental period.

The data on daily pollutant concentration considered in the analysis refer to the tenth day previous to the sampling date, which was the period elapsed between the first formation of the stamen hair in the flower bud (when the hair cellular phenotype was defined) and the actual opening up of the flower for scoring (Rodrigues, 1999a). The specific correlation coefficients were in general low (Table 1), which was insufficient to indicate strong association.

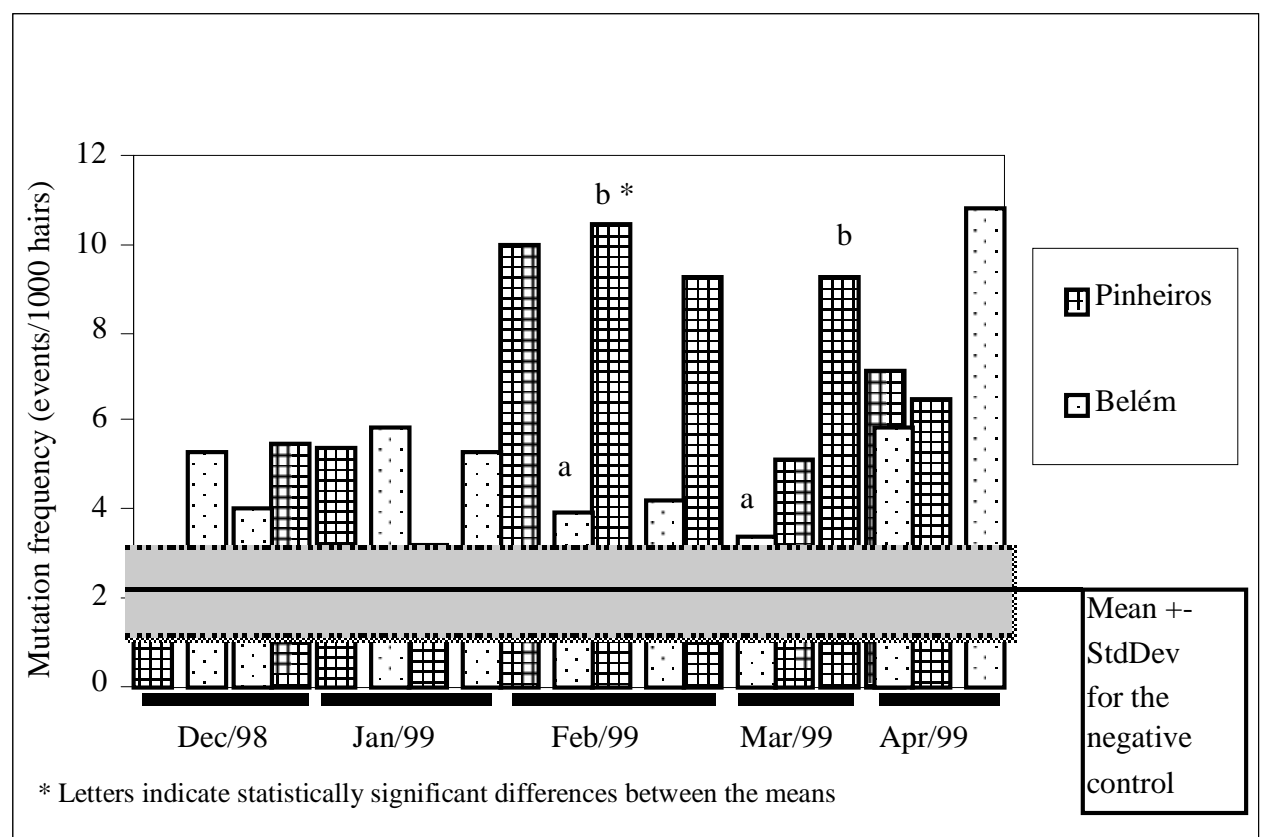

Figure 1 - Mutation frequency in Tradescantia (Trad-SHM) exposed in wo urban sites of contrasting pollution levels in São Paulo city 
Table 1 - Linear correlation coefficients between Trad-SHM mutation frequency and levels of atmospheric pollutants in São Paulo.

\begin{tabular}{lcccc}
\hline Pollutant - Period & $\mathbf{C O}$ & $\mathbf{S O}_{2}$ & $\mathbf{N O}_{2}$ & $\boldsymbol{P M}$ \\
\hline Monthly & -- & 0.24 & 0.02 & - \\
Daily & 0.19 & 0.16 & 0.19 & 0.41 \\
\hline
\end{tabular}

Only particulate matter concentration presented a positive association with mutation frequency, as indicated by the correlation coefficient shown in Table 1, and as can be seen in Fig. 2.

This result was in agreement with the arguments of Batalha and coworkers (1999), that soluble fractions of particulate matter present in the atmosphere of São Paulo were capable of inducing significant increases in mutation rate in exposed Tradescantia.

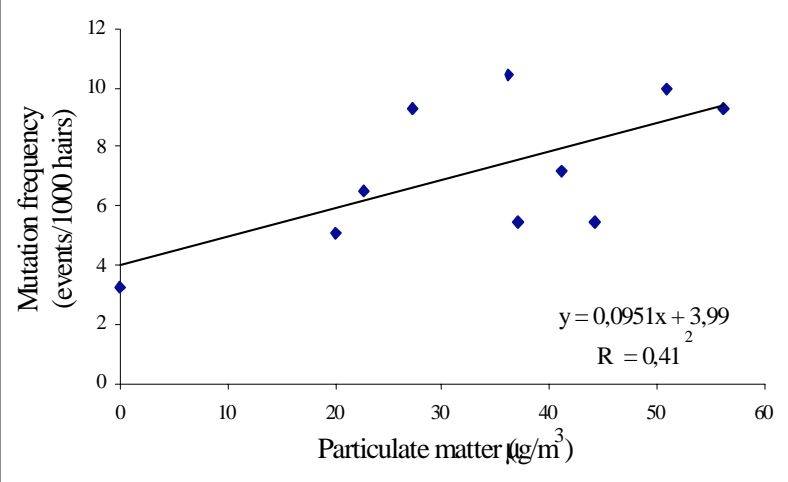

Figure 2 - Linear correlation between mutation frequency in Tradescantia and levels of atmospheric particulate

\section{DISCUSSION}

The data obtained in this study (Fig. 1) were in agreement with those found by Schairer and coworkers (1979) in an extensive monitoring study carried out in 18 areas of the USA. Using the same Trad-SHM assay, the mutation frequency observed in the pristine Grand Canyon National Park (Arizona State) was significantly smaller than the one observed in the State of New Jersey, where there were oil refineries and heavy vehicle traffic. According to these authors, this implicated a relationship between environmental mutagenesis and fossil fuel processing and consumption.
Since the beginning of the century, the Belém neighborhood shows important industrial activity, mainly of the transformation sector. Up to 1995 , there were 278 industrial establishments, being 24 metallurgical, 21 of electronic components, and 20 mechanical; being the balance (213 establishments) not related to atmospheric pollutant emissions. According to the Company of Traffic Engineering of São Paulo (CET), the average daily traffic in Celso Garcia Avenue was 8,750 vehicles (based on data of 1998).

Pinheiros neighborhood is considered residential, however, over the last decades some important industries have been established. In 1995 there were 142 industrial establishments, 37 related to apparel and textiles, 15 to food processing, and 14 to electric-electronic equipment (remaining establishments not related to atmospheric pollutant emissions). The average daily traffic volume in Dr. Arnaldo Avenue was 46,125 vehicles (data for 1998).

Over the last few years, the city of São Paulo has witnessed a substantial increase in pollution level due to an increase in vehicular traffic. On the other hand, urbanization brought an increase in the levels of particulate matter. The traffic in Pinheiros neighborhood was five-fold that of Belém neighborhood. Dr. Arnaldo Avenue (exposure site for Pinheiros neighborhood) is the junction of three main traffic corridors of the downtown area. Thus, the increase in mutation observed in the Trad-SHM assay for Pinheiros neighborhood in comparison with Belém neighborhood was most likely a consequence of the vehicular sources.

Taking into consideration the fact that the country was in recession during the experimental period, thus the industry was operating below its normal capacity, the neighborhood which was expected to reflect the effects of a reduction in the industrial activity was exactly Belém (personal communication, Municipal Planning Secretary). This corroborated the hypothesis that motor 
vehicles were the main sources of genotoxic pollution.

The relationship established between mutation frequency and the levels of atmospheric particulate matter indicated that special attention should be addressed to this component of the atmospheric pollution. The role of ozone pollution (Rodrigues et al., 1996) could be of importance, and should be investigated in the future. Additionally, studies that promote the comparison between the results obtained with plant bioassays such as the present case, and assays of genotoxic endpoints in mammalian biomarkers (especially in mouse and humans) should be encouraged, aiming at policy initiatives to improve measures of pollution control and protection of populations in relation to genotoxic environmental contaminants.

\section{ACKNOWLEDGEMENTS}

The authors are grateful to the Conselho Nacional de Desenvolvimento Científico e Tecnológico $(\mathrm{CNPq})$ for the support to this research.

\section{RESUMO}

O bioensaio de mutação em pêlos estaminais de Tradescantia (clone 4430) (Trad-SHM) foi utilizado para a avaliação comparativa da mutagênese ambiental em duas áreas do centro urbano de São Paulo durante a estação chuvosa, aquela mais propícia à dispersão dos poluentes atmosféricos. Os locais de exposição foram a Avenida Celso Garcia, uma área de pequenas indústrias no Bairro Belém, com um volume médio diário de tráfego de 8.750 veículos automotores e a Avenida Doutor Arnaldo, na área central (Bairro Pinheiros) com ocupação predominantemente residencial e comercial, mas com um volume médio diário de tráfego de 46.125 veículos. O controle negativo foi localizado na cidade de Jaguariúna, a 138 km de São Paulo, em uma área com baixos níveis de poluição atmosférica. Plantas de Tradescantia foram expostas cronicamente em vasos contendo solo padronizado, amostradas bimensalmente e a frequiência de mutações nos pêlos estaminais foi comparada por ANOVA $(\square=0,05)$. A freqüência de mutações observada para o Belém foi similar ao controle para o clone 4430, enquanto as plantas expostas em Pinheiros apresentaram aumentos significativos nas taxas de mutação. Certa correlação foi observada entre a frequiência de mutações e os níveis de material particulado na atmosfera. Isto indica uma associação entre taxa de mutação detectada pelo ensaio Trad-SHM e a poluição presente em locais sujeitos a maiores níveis de poluição atmosférica, em especial aquela derivada de fontes veiculares.

\section{REFERENCES}

Batalha, J. R. F.; Guimarães, E. T.; Lobo, D. J. A.; Lichtenfels, A. J. F. C.; Deur, T.; Carvalho, H. A.; Alves, E. S.; Domingos, M.; Rodrigues, G. S. and Saldiva, P. H. N. (1999), Exploring the clastogenic effects of air pollutants in São Paulo (Brazil) using the Tradescantia micronuclei assay. Mutat. Res., 426, 229-232.

CETESB - Companhia de Tecnologia de Saneamento Ambiental (1998), Relatório de qualidade do ar no Estado de São Paulo 1997. CETESB, São Paulo, Brazil.

Ferreira, M. I.; Petrenko, H.; Lobo, D. J. de A.; Moreira, A.; Rodrigues, G. S. and Saldiva, P. H. N. (2000), In situ evaluation of the mutagenic effects of the emissions of a waste incinerator in metropolitan São Paulo using the Tradescantia stamen hair bioassay. J. Air Waste Manag. Ass. [In press].

IBGE - Instituto Brasileiro de Geografia e Estatística (1977), Contagem da população 1996. FIBGE, Rio de Janeiro, Brazil.

Ichikawa, S. (1992), Tradescantia stamen-hair system as na excellent botanical tester of mutagenicity: its response to ionizing radiations and chemical mutagens, and some synergistic effects found. Mutat. Res., 270, 3-22.

Lower, W. R.; Drobney, V. K.; Aholt, B. J. and Politte, R. (1983a), Mutagenicity of the environments in the vicinity of na oil refinery and a petrochemical complex. Terat. Carcin. Mut., 3, 65-73.

Lower, W. R.; Rose, P. S. and Drobney, V. K. (1978), In situ mutagenic and other effects associated with lead smelting. Mutat. Res., 54, 83-93.

Lower, W. R.; Thompson, W. A.; Drobney, V. K. and Yanders, A. F. (1983b), Mutagenicity in the vicinity of a lead smelter. Terat. Carcin. Mut., 3, 231-253.

Miyazato, C. A. (2000), Avaliação in loco do potencial clastogênico do ambiente de trabalho em um laboratório clínico, através do bioensaio de micronúcleo em Tradescantia pallida. PhD Thesis, Universidade de São Paulo, São Paulo, Brazil. 
Rodrigues, G. S. (1999a), Bioensaios de Toxicidade Genética com Plantas Superiores: Tradescantia (MCN, SHM), Milho e Soja. Embrapa Meio Ambiente, Circular Técnica 02. Jaguariúna, 30 pp.

Rodrigues, G. S. (1999b), Bioensaios de Toxicidade Genética com Tradescantia. Embrapa Meio Ambiente, Documentos 14. Jaguariúna, 56 pp.

Rodrigues, G. S. (1999c), Pesticidas e Toxicidade Genética. Detecção e Monitoramento com Bioensaios Vegetais: Milho e Soja. Embrapa Meio Ambiente, Documentos 13. Jaguariúna, 30 pp.

Rodrigues, G. S.; M. T. H.; Pimentel, D. and Weinstein, L. H. (1997), Tradescantia bioassays as monitoring systems for environmental mutagenesis - a review. Crit. Ver. Plant Sci., 16, 325-359.

Rodrigues, G. S.; Madkour, S. A. and Weinstein, L. H. (1996), Genotoxic activity of ozone in Tradescantia. Envir. Exp. Bot., 36, 45-50.

Sadowska, A.; Pluygers, E.; Narkiewicz, M.; Pawelczak, A. and Lata, B. (1994), Environmental genotoxicity and cancer risk in humans: a combined evaluation correlating the results of the Tradescantia micronucleus assay in the field and human biomarker assessments in serum. I - The Trad-MCN assay. Eur. J. Cancer Prev., 3, 69-78.

Schairer, L. A. (1979), Mutagenicity of ambient air at selected sites in the United States using Tradescantia as a monitor. In: Kolber, T. K.; Grant, L. D.; DeWoskin, R. S. and Hughes, T. J. (eds.). In Situ Toxicity Testing of Environmental Agents. Current and Future Possibilities - Part A: Survey of Test Systems. New York : Plenum Press.

Schairer, L. A. and Sautkulis, R. C. (1982), Detection of ambient levels of mutagenic atmospheric pollutants with the higher plant Tradescantia. In: Environmental Mutagenesis, Carcinogenesis, and Plant Biology, ed. E. J. Klekowski. Praeger, New York.

Schairer, L. A.; Sautkulis, R. C. and Tempel, N. R. (1982), Monitoring ambient air for mutagenicity using the higher plant Tradescantia. In: Genotoxic Effects of Airborne Agents, eds. R. R. Tice; D. L. Costa; K. M. Schaich. Plenum Press, New York.

Snedecor, G. W. and Cochran, W. G. (1967), Statistical Methods. The Iowa State University Press, Ames.
Sparrow, A. H. and Schairer, L. A. (1974), The effects of chemical mutagens (Sem, DBE) and specific air pollutants $\left(\mathrm{O}_{3}, \mathrm{SO}_{2}, \mathrm{NO}_{2}, \mathrm{~N}_{2} \mathrm{O}\right)$ on somatic mutation rate in Tradescantia. In: Bubinin, N. P. (ed.). Genetic Effects of Pollution in the Environment. Institute Obshchei Genetiki, Moscow.

Underbrink, A. G.; Schairer, L. A. and Sparrow, A. H. (1973), Tradescantia stamen hairs: a radiobiological test system applicable to chemical mutagenesis. In: Hollaender, A. (ed.). Chemical Mutagens Principles and Methods for Their Detection. Plenum Press, New York.
Received: November 01, 2000; Revised: September 24, 2001; Accepted: August 23, 2002. 